\author{
Caruso $\mathrm{G}^{1 \star}$ and Caruso $\mathrm{R}^{2}$ \\ ${ }^{1}$ National Research Council, Institute for Coastal \\ Marine Environment (CNR-IAMC), Messina, Italy \\ ${ }^{2}$ Hospital Agency A.O.U. "G. Martino", Messina, \\ Italy
}

Dates: Received: 16 December, 2015; Accepted: 30 December, 2015: Published: 31 December, 2015

*Corresponding author: Gabriella Caruso, Graduate in Biological Sciences, Specialist in Applied Microbiology. Researcher at: CNR-IAMC, Address: Spianata S. Raineri 86, 98122 Messina, Italy, Tel: +39-0906015423; Fax: +39-090669007; E-mail: gabriella.caruso@iamc.cnr.it

www.peertechz.com

Keywords: Seawater; Coastal monitoring; Escherichia coli; Viability; CTC; P

\section{Research Article \\ Escherichia Coli Viability in Coastal Marine Environments: A Case Study}

\begin{abstract}
Background: The assessment of the bacteriological quality of coastal marine waters through the search of Escherichia coli as an indicator of fecal pollution is a topic of public concern.

The context and purpose of the study: During a coastal monitoring program, the abundance and distribution of the actively respiring and dead fraction within the total $E$. coli population along the Messina coastline (Sicily, Italy) were investigated using a fluorescent-antibody method coupled with the stains 5-cyano-2,3-ditolyl tetrazolium chloride (CTC) or propidium iodide (PI) in order to assess the potential risk related to the viability of this microorganism
\end{abstract}

Results: This study confirm that the proposed analytical protocols are suitable for $E$. coli monitoring in seawater, providing in a short time (less than 2 hours from sampling) results comparable to plate count methods currently in use.

Main findings: The obtained $E$. coli counts showed spatial and temporal variations - although not significant - in the percentage of CTC+ cells, suggesting that some cells were still retaining their viability properties, and their abundance was affected by the presence of streams and by the hydrodynamic regimen of the Messina Straits.

Conclusions: This study is a contribution to the knowledge of the distribution and viability properties of $E$. coli present in the waters of Messina coastline in terms of its active and dead components.

Brief summary: The cell viability assay through fluorescent antibody and viability dyes offers an interesting research perspective, with important implications for a more reliable estimate of the bacteriological quality of seawater.

Any potential implications: The determination of the different physiological states coexisting within the $E$. coli population is of great significance for human health protection, since it may provide information on the effective risk played by the living component of this microorganism.

\section{Abbreviations}

E. coli: Escherichia Coli; FC: Fecal Coliforms; FA: Fluorescent Antibody; FITC: Fluorescein Isothiocyanate Conjugate; CTC: 5-Cyano-2,3-ditolyl Tetrazolium Chloride; VBNC: Viable But Not Culturable; PI: Propidium Iodide; DVC: Direct Viable Count;

\section{Introduction}

The assessment of the bacteriological quality of coastal waters is a topic of public concern and has important implications on the activities (i.e. aquaculture, fishing, tourism) pursued in coastal and transitional areas. The anthropogenic impact on coastal environments is a function of the human density along the coasts, assuming different aspects, such as eutrophication, spread of sewage wastes or organic pollution. The pollutant inputs cause the worsening of water quality, resulting in limitations of their recreational and productive uses, and involving serious risks to human health. The risk of contracting waterborne diseases is strictly dependent on the level of fecal pollution of aquatic environments. The monitoring of the health quality of coastal waters is critical to readily detect areas exposed to potential pollution ("early warning") and establish appropriate remediation measures in order to prevent the outbreak of infectious diseases.

Escherichia coli is recognized as the main bacterial indicator of faecal contamination for monitoring the hygienico-sanitary quality of coastal seawater for recreational use $[1,2]$.

The search for rapid analytical methods for the detection of bacterial pathogens in seawater aims at overcoming the limitations of conventional culture methods in terms of long analysis times and response, which hinder their application in environmental monitoring.

Of particular interest is also the assessment of cell viability of fecal bacteria, which is crucial for human safety. The enteric bacteria introduced in the aquatic environment can survive in a "Viable But Not Culturable" state [3]; under this form, they lose the ability to grow on culture media, keeping however some physiological activities, with potential risks related to the possibility of recovery of pathogenicity when environmental conditions become favorable [4]. This underlines the importance of determining the physiological state of potentially pathogenic bacteria present in the water.

The present note refers to the distribution of E. coli cells in some coastal sites along the town of Messina (Sicily, Italy), focusing in particular on the fraction of cells keeping some viability properties, such as culturability, active respiratory metabolism and membrane integrity. To this goal, a protocol based on the combination of a typical indirect fluorescent antibody (FA) method with the viability 
stains 5-cyano-2,3-ditolyl tetrazolium chloride (CTC) and propidium iodide (PI) was used.

\section{Materials and Methods}

\section{Seawater sampling}

Five stations located along the shoreline of the Messina Straits, further indicated as North coastline, Annunziata stream, S. Francis Pier, Europa and Tremestieri (Figure 1), were sampled during several months, June, October-December, January, March-April, corresponding to the summer, autumn, Winter and Spring seasons, respectively. A sterile plastic bottle was used for collection of 1-litre sample, which was kept at $+5^{\circ} \mathrm{C}$ until analysis and treated within 2 hours from sampling.

\section{Analytical protocols}

Culture counts were performed through membrane filtration ( $0.45 \mu \mathrm{m}$ pore size) followed by incubation on $\mathrm{m}$-FC agar plates, according to APHA [5].

For the microscopical analysis, the cell labeling protocols which combined the fluorescent antibody technique (FA) with the staining with 5-cyano-2,3-ditolyl tetrazolium chloride (CTC) or propidium iodide (PI) dyes [6], were used in this study. The cell viability assay (FA-CTC and FA-PI) was developed in the framework of the CLUSTER-SAM project as a further development of FA method [7], specifically designed for E.coli detection in seawater, in order to target separately two different cell viability traits such as the presence of an active metabolism (CTC) or an integer cell membrane (PI). In fact, PI and CTC are able to label selectively cells dead or with damaged cell membranes [8] and actively respiring cells, respectively, by binding to the nuclear and cytoplasmic portions, while immune sera conjugated with fluorescein isothiocyanate (FITC) recognize antigenic determinants present on the surface of both living and dead cells.

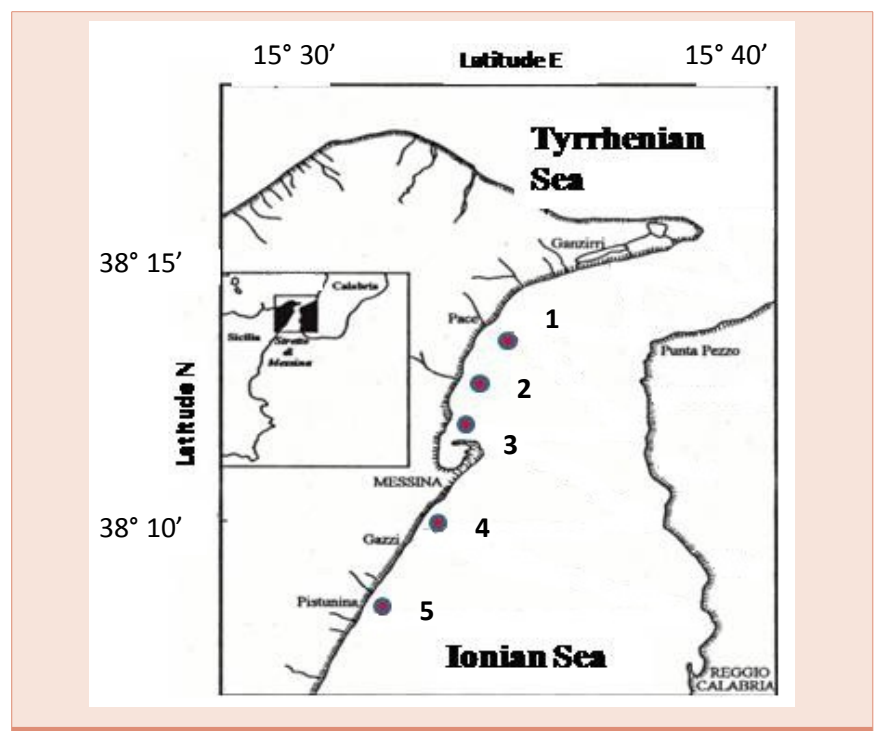

Figure 1: Coastal sites under study: 1 - North coastline, 2 -Annunziata, 3 - S. Francis Pier, 4 - Europa, 5 - Tremestieri.
Treatment with 5-ciano-2,3-ditolyl tetrazolium chloride (CTC).

The assessment of actively respiring $E$. coli cells was performed using 5-ciano-2,3-ditolyl tetrazolium chloride (CTC, Polyscience. Warrington. $\mathrm{Pa}$ ), a redox stain that in presence of oxygen is reduced into formazan, which precipitates intracellularly as red fluorescing granules, so allowing the detection of actively respiring cells under epifluorescence microscope [9-11]. In our study, $100 \mathrm{ml}$ of sample was incubated with $5 \mathrm{mmol} / \mathrm{l} \mathrm{CTC} \mathrm{(final} \mathrm{concentration)} \mathrm{for} 90 \mathrm{~min}$ in the dark at room temperature and then filtered through a Nuclepore polycarbonate black membrane $(0.22-\mu \mathrm{m}$ pore size). After treatment with hydrolysed gelatine ( $\mathrm{pH}$ 7.2), the filter was first labelled with Murex E. coli agglutinating sera specific for enteropathogenic serotypes (pools $2+3+4,1: 40$ dilution, $30 \mathrm{~min}$ at room temperature) and then with goat anti rabbit fluorescein isothiocyanate (FITC)conjugated IgG (Sigma) (1:80 dilution, $30 \mathrm{~min}$ at room temperature).

\section{Treatment with propidium iodide (PI)}

For the estimation of the non-viable E. coli cells, a $100 \mathrm{ml}$ volume of sample was filtered on a Nuclepore polycarbonate black membrane $(0.22-\mu \mathrm{m}$ pore size) and the filter incubated in the dark with propidium iodide (PI, Sigma-Aldrich, St. Louis, MO, USA; final concentration: $0.01 \mathrm{mg} / \mathrm{l}$ ) for 5 minutes at room temperature. Then, labelling with polyclonal antisera and FITC conjugate was performed as described above for FA-CTC procedure.

\section{Microscopical observation}

The filter obtained after treatment with CTC or PI was further mounted on a glass slide using a drop of Immersoil 158F (Zeiss). Counts were made on at least 20 microscopic fields with a Zeiss Axioplan 2 epifluorescence microscope (Carl Zeiss Vision GmbH, Munchen, Germany) coupled with an image analysis system, equipped with a $100 \mathrm{~W}$ mercury lamp. Total FA labelled cells were quantified under blue light (450-490 $\mathrm{nm}$ ) for FITC excitation; the viable and actively respiring cells- which showed bright red fluorescence because of CTC-formazan crystals - were scored as CTC-positive (CTC+) cells by observation under a green combination filter block, such as the Rhodamine filter set (green light, BP 510-560, FT 580 and LP 590). Under green light excitation, dead, PI-positive, cells were visualized as red fluorescing cells, due to the PI emission spectra (peak value: 617- $623 \mathrm{~nm}$ ). All the microscopical counts were expressed as the mean value of cells observed per $100 \mathrm{ml}$ of sample (cells/100 ml).

\section{Statistical analysis of data}

The bacterial counts obtained during this study are reported as the monthly range (minimum-maximum) and the geometric mean calculated per each station. To get more indication of the variability among samples collected within each station, a coefficient of variation (CV) was calculated using the formula

\section{$\mathrm{CV}=(\text { Standard deviation } / \text { Mean })^{\star} 100$.}

To assess the statistical significance of differences among quantitative data, two-ways analysis of variance (ANOVA) was carried out using "stations" and "sampling times" as the two main factors. Prior to analysis, all the values were normalized by logarithmic transformation. 


\section{Results}

An example of microscopical field showing the typical morphological feature of $E$. coli cells after labelling with FA-CTC and FA-PI protocols is shown in the Figure 2.

The plate (FC) and total immunofluorescence (total FA) counts, together with the fraction of the CTC+ and PI+ cells and their relative percentage calculated on the total FA counts at each station during each month, are reported in Table 1. More in detail, the abundance of culturable E.coli (FC) showed lower values at the North coastline and followed an increasing trend moving towards the southern stations (Tremestieri). The minimum (3 CFU/100 ml) and maximum $\left(1.3 \times 10^{4}\right.$ $\mathrm{CFU} / 100 \mathrm{ml}$ ) concentrations by FC were recorded at Annunziata stream in April and at Tremestieri station in January,, respectively. The microscopical E. coli counts (total FA) ranged from a minimum value of $6.0 \times 10^{2}$ cells $/ 100 \mathrm{ml}$, North Coastline (June) to maximum values of $4.5 \times 10^{5}$ cells $/ 100 \mathrm{ml}$ (S. Francis Pier, March) and $2.7 \times 10^{5}$ cells/100 ml at station Tremestieri. High CV values (exceeding 200) suggested the highest monthly variability of bacterial load at $\mathrm{S}$. Francis Pier, while the lowest variability was found at Tremestieri and at North Coastline, where coefficients of variation close to 100 were calculated.

Figure 3 compares the E. coli counts obtained by FC and FA methods at each sampling station and time. A difference of 1-2 orders of magnitude in their respective values was observed; however,

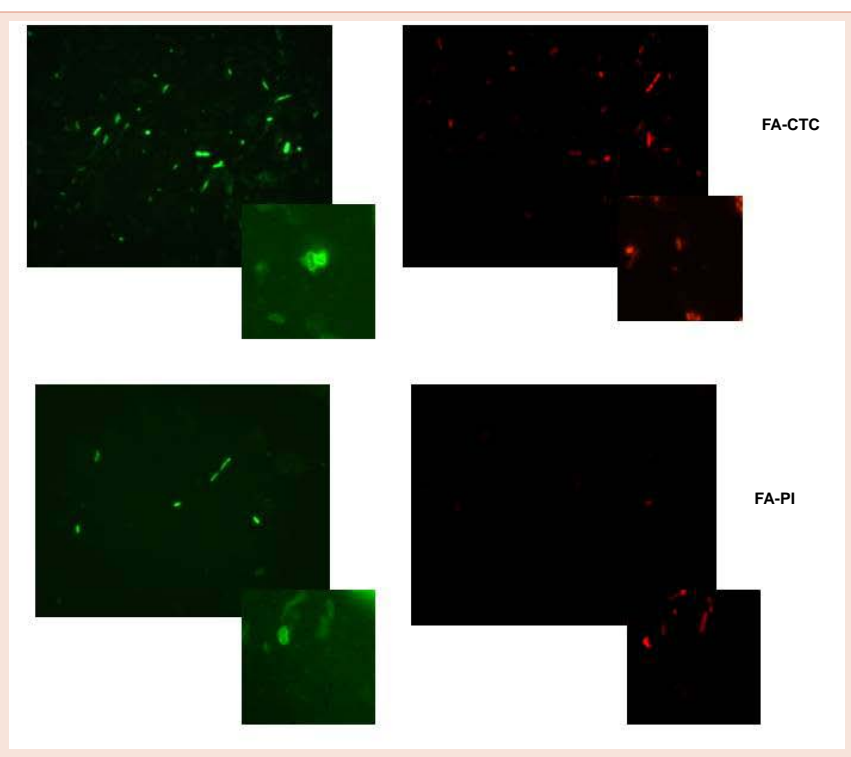

Figure 2: Escherichia coli cells examined under an epifluorescence microscope (Zeiss Axioplan 2, magnification X1000; BP 450-490 filter set for FITC-blue light, given a green fluorescence emission, and BP 510-560 filter for Rhodamine-green light, given a red fluorescence emission)

Upper Images: on the left, E. coli stained with the green FITC-labelled immune sera (total Fluorescent antibody cells, total FA cells); on the right, bacteria stained with 5-cyano-2,3-ditolyl tetrazolium chloride (CTC, a marker of actively respiring cells)

Lower Images: on the left, E. coli stained with the green FITC-labelled immune sera (total Fluorescent antibody cells, total FA cells); on the right, bacteria stained with propidium iodide (PI, a marker of dead cells), respectively-

The small Picture shows in details how a typically stained cell appears the analysis of variance (ANOVA test) pointed out no significant differences among the sampling stations (except for the Tremestieri station with respect to $\mathrm{FC}$ counts, $\mathrm{F}=8.21, \mathrm{P}<0.001)$ and the sampling times.

The CTC+ counts (Table 1) varied between $4.8 \times 10^{1}$ and $4.4 \times 10^{5}$ cells/100 ml, measured at the North coastline and S. Francis Pier at the same times as reported for total FA. The PI+ cells were detected in lower concentrations, ranging from 1 (recorded at Europa, Annunziata and S. Francis station in March-April) to $7.6 \times 10^{4}$ cells/100 $\mathrm{ml}$ (recorded at Tremestieri station in January).

Considering the relative contribution to the total E. coli population of the two components (actively respiring and dead cells labelled by CTC and PI respectively), the highest percentages of actively respiring bacteria on the total FA counts (ranging from 62 to $84 \%$ of the total) were detected at the stations S. Francis Pier, Europa and Annunziata stream; conversely, lower percentages of CTC+ cells ( $21 \%$ of the total) were found at Tremestieri (Table 1). The PI counts followed trends similar to total FA counts, increasing towards the southern stations; the highest percentage contribution of PI+ cells to the total E. coli population was recorded at Tremestieri and Europa stations (21\% of the total), the lowest one at the Annunziata stream (7\% of the total) (Table 1). The percentages of CTC+ and PI+ cells on the total FA counts, averaged per each station (Figure 4), pointed out that, added together, the bacterial cells labelled by CTC and by PI accounted for most of the whole E.coli population present in the waters, reaching percentages of $90-94 \%$ of total FA counts at Europa and S. Francis Pier, respectively. Conversely, at Tremestieri station E.coli cells not labelled by both dyes accounted for $41 \%$ of total FA.

On a temporal scale, the seasonally averaged data - shown in Figure 5 - highlighted that FC counts were one order of magnitude higher in colder months (winter-spring) compared to warmer ones (summerautumn). Except for the low E.coli abundances found in summer, seasonal variations in the total FA counts were not significant. The distribution of CTC+ and PI+ described opposite patterns. In spring the actively respiring cells predominated; their abundance decreased in winter, probably due to low water temperatures. This result was in agreement with the highest concentrations of PI+ cells observed in autumn-winter compared to spring-summer, suggesting higher bacterial "die-off". Low numbers of CTC+ cells were also recorded in summer, suggesting bacterial inhibition by sunlight.

\section{Discussion}

This study is a contribution to the knowledge of the distribution and viability properties of $E$. coli present in the waters of Messina coastline in terms of its active and dead components. The determination of the different physiological states coexisting within the E. coli population is of great significance for human health protection, since it may provide information on the effective risk played by the living component of this microorganism.

The spatial distribution of E.coli concentrations showed a north to south increasing trend; this distribution reflected the hydrological dynamic regimen of the Straits of Messina, and the prevailing current conditions ("scendente current", from North to South) recorded during all the sampling dates. Total FA values were also affected by 
Table 1: Abundance of Escherichia coli found at the examined stations in terms of culturable bacteria on m-FC plates (FC), total cells labelled by fluorescent antibody method (total FA), actively respiring (CTC+) and dead $(\mathrm{PI}+)$ cells labelled by 5 -cyano-2,3-ditolyl tetrazolium chloride and propidium iodide, respectively, and the relative percentage of these two components on the total FA counts. The monthly range (minimum-maximum) or single value, the geometric mean (GM) of the concentrations and their coefficient of variation (CV, as the Standard deviation/Mean $\times 100)$ are reported.

\begin{tabular}{|c|c|c|c|c|c|c|c|c|c|c|c|c|c|}
\hline & $\mathrm{N}$ & $\begin{array}{l}\text { Range } \\
\text { or value }\end{array}$ & GM & CV & $\begin{array}{l}\text { Range } \\
\text { or value }\end{array}$ & GM & $\mathrm{CV}$ & $\begin{array}{l}\text { Range } \\
\text { or value }\end{array}$ & GM & $\begin{array}{l}\text { Range } \\
\text { or value }\end{array}$ & GM & CV & \\
\hline \multirow{2}{*}{\multicolumn{2}{|c|}{$\begin{array}{l}\text { North } \\
\text { coastline }\end{array}$}} & CFU/100 ml & & & cells $/ 100 \mathrm{ml}$ & & & cells/100 ml & & cells/100 ml & & \multirow{2}{*}{$\begin{array}{l}\text { Mean } \\
\% \\
\text { CTC+/ } \\
\text { FA }\end{array}$} & \multirow{2}{*}{$\begin{array}{l}\text { Mean } \\
\% \\
\mathrm{PI}+/ \\
\mathrm{FA}\end{array}$} \\
\hline & & $\mathrm{FC}$ & & & Total FA & & & CTC+ & & $\mathrm{Pl}+$ & & & \\
\hline Jun & 2 & $7.8 \mathrm{E}+00-1.4 \mathrm{E}+01$ & $1.0 \mathrm{E}+01$ & & $6.0 \mathrm{E}+02-7.6 \mathrm{E}+02$ & $6.7 \mathrm{E}+02$ & & $4.8 \mathrm{E}+01-1.8 \mathrm{E}+02$ & $9.3 \mathrm{E}+01$ & $4.0 \mathrm{E}+02-4.3 \mathrm{E}+02$ & $4.1 \mathrm{E}+02$ & 16 & 62 \\
\hline Oct & 2 & $8.8 \mathrm{E}+01-1.0 \mathrm{E}+02$ & $9.4 \mathrm{E}+01$ & & $3.0 \mathrm{E}+04-3.2 \mathrm{E}+04$ & $3.1 \mathrm{E}+04$ & & $8.0 \mathrm{E}+03-2.3 \mathrm{E}+04$ & $1.4 \mathrm{E}+04$ & $4.3 E+03-5.7 E+03$ & $4.9 \mathrm{E}+03$ & 49 & 16 \\
\hline Jan & 2 & $1.1 \mathrm{E}+01-2.8 \mathrm{E}+01$ & 1.7E+01 & & $3.7 \mathrm{E}+03-1.3 \mathrm{E}+04$ & $6.9 \mathrm{E}+03$ & & $2.6 \mathrm{E}+03-9.6 \mathrm{E}+03$ & $5.0 \mathrm{E}+03$ & $3.8 \mathrm{E}+02-3.3 \mathrm{E}+03$ & $1.1 \mathrm{E}+03$ & 72 & 18 \\
\hline Apr & 2 & $5.0+E 00-5.8 E+00$ & $5.4 \mathrm{E}+00$ & & $2.1 \mathrm{E}+03-2.5 \mathrm{E}+03$ & $2.3 \mathrm{E}+03$ & & $1.2 \mathrm{E}+03-1.8 \mathrm{E}+03$ & $1.5 \mathrm{E}+03$ & $3.7 \mathrm{E}+02-3.8 \mathrm{E}+02$ & $3.7 \mathrm{E}+02$ & 65 & 16 \\
\hline
\end{tabular}

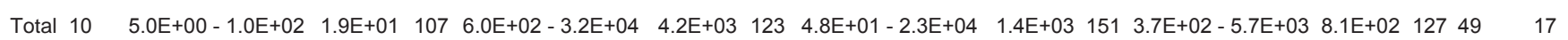
Annunziata

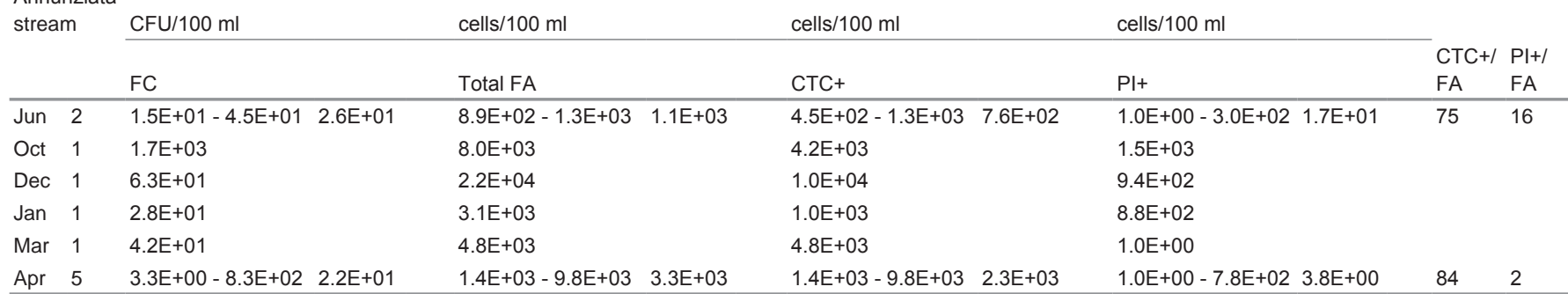

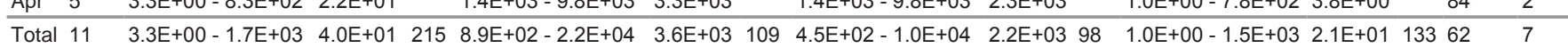

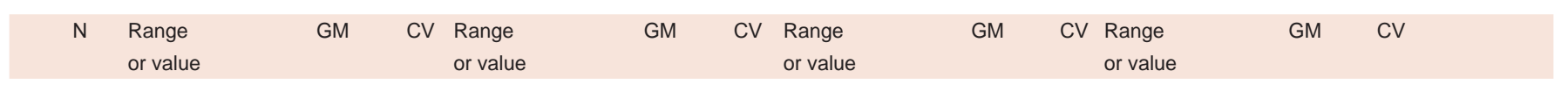

S. Francis

Pier CFU/100 mis

\begin{tabular}{ll} 
FC \\
\hline Jun 3 & $9.0 \mathrm{E}+01-4.6 \mathrm{E}+02 \quad 2.0+\mathrm{E} 02$
\end{tabular}

Oct $2 \quad 4.6 \mathrm{E}+02-5.2 \mathrm{E}+02 \quad 4.9 \mathrm{E}+02$

Dec $2 \quad 1.9 \mathrm{E}+02-3.1 \mathrm{E}+02 \quad 2.4 \mathrm{E}+02$

Jan $2 \quad 3.5 E+01-5.2 E+01 \quad 4.3 E+01$

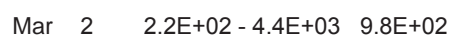

Apr $6 \quad 1.1 \mathrm{E}+01-3.9 \mathrm{E}+02 \quad 1.1 \mathrm{E}+02$ cells/100 ml

cells $/ 100 \mathrm{ml}$

CTC+/ Pl+l

\section{Total FA}

$1.2 \mathrm{E}+03-3.3 \mathrm{E}+03 \quad 1.8 \mathrm{E}+03$

$4.3 \mathrm{E}+03-4.8 \mathrm{E}+03 \quad 4.5 \mathrm{E}+03$

$3.6 \mathrm{E}+04-4.2 \mathrm{E}+04 \quad 3.9 \mathrm{E}+04$

$1.1 \mathrm{E}+03-5.1 \mathrm{E}+03 \quad 2.4 \mathrm{E}+03$

$1.9 \mathrm{E}+04-4.5 \mathrm{E}+05 \quad 9.2 \mathrm{E}+04$

$1.0 \mathrm{E}+03-4.0 \mathrm{E}+03 \quad 2.1 \mathrm{E}+03$
CTC+

$8.0 \mathrm{E}+02-3.3 \mathrm{E}+03 \quad 1.3 \mathrm{E}+03$

$1.8 \mathrm{E}+03-1.9 \mathrm{E}+03 \quad 1.8 \mathrm{E}+03$

$1.8 \mathrm{E}+03-1.2 \mathrm{E}+04 \quad 4.6 \mathrm{E}+03$

$6.6 \mathrm{E}+02-8.7 \mathrm{E}+02 \quad 7.6 \mathrm{E}+02$

$1.9 \mathrm{E}+04-4.4 \mathrm{E}+05 \quad 9.1 \mathrm{E}+04$

$7.6 \mathrm{E}+02-3.2 \mathrm{E}+03 \quad 1.5 \mathrm{E}+03$ $\begin{array}{lllllllllll}\text { Total } 17 & 1.1 \mathrm{E}+01-4.4 \mathrm{E}+03 & 1.8 \mathrm{E}+02 & 218 & 1.0 \mathrm{E}+03-4.5 \mathrm{E}+05 & 4.9 \mathrm{E}+03 \quad 317 & 6.6 \mathrm{E}+02-4.4 \mathrm{E}+05 \quad 2.5 \mathrm{E}+03 & 366 & 2.9 \mathrm{E}+04\end{array}$ Europa CFU/100 ml cells $/ 100 \mathrm{ml}$ cells $/ 100 \mathrm{ml}$ cells $/ 100 \mathrm{ml}$

$1.5 \mathrm{E}+03-2.1 \mathrm{E}+03 \quad 1.8 \mathrm{E}+03$

$9.8 \mathrm{E}+03-2.9 \mathrm{E}+04 \quad 1.7 \mathrm{E}+04$

$2.4 \mathrm{E}+02-4.9 \mathrm{E}+02 \quad 3.4 \mathrm{E}+02$

$1.0 \mathrm{E}+00-1.4 \mathrm{E}+04 \quad 1.2 \mathrm{E}+02$

$1.0 \mathrm{E}+00-8.0 \mathrm{E}+02 \quad 6.2 \mathrm{E}+01$

$2.1 \mathrm{E}+02 \quad 21284 \quad 10$

\begin{tabular}{|c|c|c|c|c|c|c|c|c|c|c|c|}
\hline & & FC & & Total FA & & CTC+ & & $\mathrm{Pl}+$ & & $\begin{array}{l}\mathrm{CTC}+1 \\
\text { FA }\end{array}$ & $\begin{array}{l}\mathrm{PI}+1 \\
\mathrm{FA}\end{array}$ \\
\hline Jun & 2 & $3.0 \mathrm{E}+02-4.8 \mathrm{E}+02$ & $3.8 \mathrm{E}+02$ & $1.7 \mathrm{E}+03-4.9 \mathrm{E}+03$ & $2.9 \mathrm{E}+03$ & $8.9 E+02-4.1 E+03$ & $1.9 E+03$ & $6.0 \mathrm{E}+01-8.2 \mathrm{E}+02$ & $2.2 \mathrm{E}+02$ & 68 & 10 \\
\hline Oct & 1 & $2.2 \mathrm{E}+02$ & & $1.6 \mathrm{E}+03$ & & $7.4 \mathrm{E}+02$ & & $8.9 \mathrm{E}+01$ & & 46 & 6 \\
\hline Jan & 1 & $8.8 \mathrm{E}+01$ & & $4.4 \mathrm{E}+04$ & & $2.7 \mathrm{E}+04$ & & $5.4 \mathrm{E}+03$ & & 61 & 12 \\
\hline Mar & 2 & $3.3 E+03-3.5 E+03$ & $3.4 \mathrm{E}+03$ & $3.2 \mathrm{E}+04-6.2 \mathrm{E}+04$ & $4.4 \mathrm{E}+04$ & $3.2 E+04-6.2 E+04$ & $4.4 \mathrm{E}+04$ & $1.0 \mathrm{E}+00-2.0 \mathrm{E}+00$ & $1.0 \mathrm{E}+00$ & 100 & 0 \\
\hline Apr & 4 & $3.2 \mathrm{E}+02-7.5 \mathrm{E}+02$ & $4.8 \mathrm{E}+02$ & $4.3 \mathrm{E}+03-9.2 \mathrm{E}+03$ & $5.8 \mathrm{E}+03$ & $2.9 \mathrm{E}+03-5.8 \mathrm{E}+03$ & $4.2 \mathrm{E}+03$ & $1.0 \mathrm{E}+00-5.2 \mathrm{E}+03$ & $5.2 E+01$ & 77 & 22 \\
\hline Total & Tremestieri & $\mathrm{FC}$ & & Total FA & & CTC+ & & $\mathrm{Pl}+$ & & $\begin{array}{l}\mathrm{CTC}^{+1} \\
\mathrm{FA}\end{array}$ & $\begin{array}{l}\mathrm{PI}+1 \\
\mathrm{FA}\end{array}$ \\
\hline Dec & 2 & $4.8 \mathrm{E}+02-5.0 \mathrm{E}+02$ & $5.0 \mathrm{E}+02$ & $5.4 \mathrm{E}+04-6.7 \mathrm{E}+04$ & $6.0 \mathrm{E}+04$ & $2.5 \mathrm{E}+02-3.7 \mathrm{E}+04$ & $3.0 \mathrm{E}+03$ & $2.8 \mathrm{E}+03-1.1 \mathrm{E}+04$ & $5.5 \mathrm{E}+03$ & 28 & 11 \\
\hline Jan & 2 & $7.8 E+03-1.3 E+04$ & $1.0 \mathrm{E}+04$ & $6.1 \mathrm{E}+03-2.7 \mathrm{E}+05$ & $4.0 \mathrm{E}+04$ & $1.8 \mathrm{E}+03-5.0 \mathrm{E}+03$ & $3.0 \mathrm{E}+03$ & $7.8 \mathrm{E}+02-7.6 \mathrm{E}+04$ & $7.7 \mathrm{E}+03$ & 16 & 20 \\
\hline Mar & 2 & $2.0 \mathrm{E}+02-3.8 \mathrm{E}+02$ & $2.7 \mathrm{E}+02$ & $8.1 E+03-2.7 E+04$ & $1.5 \mathrm{E}+04$ & $8.1 E+03-2.7 E+04$ & $1.5 \mathrm{E}+04$ & $1.0 \mathrm{E}+00-2.0 \mathrm{E}+00$ & $1.0 \mathrm{E}+00$ & 100 & 0 \\
\hline Apr & 1 & $9.2 \mathrm{E}+03$ & & $2.4 \mathrm{E}+04$ & & $1.7 \mathrm{E}+04$ & & $6.9 \mathrm{E}+03$ & & 71 & 29 \\
\hline
\end{tabular}




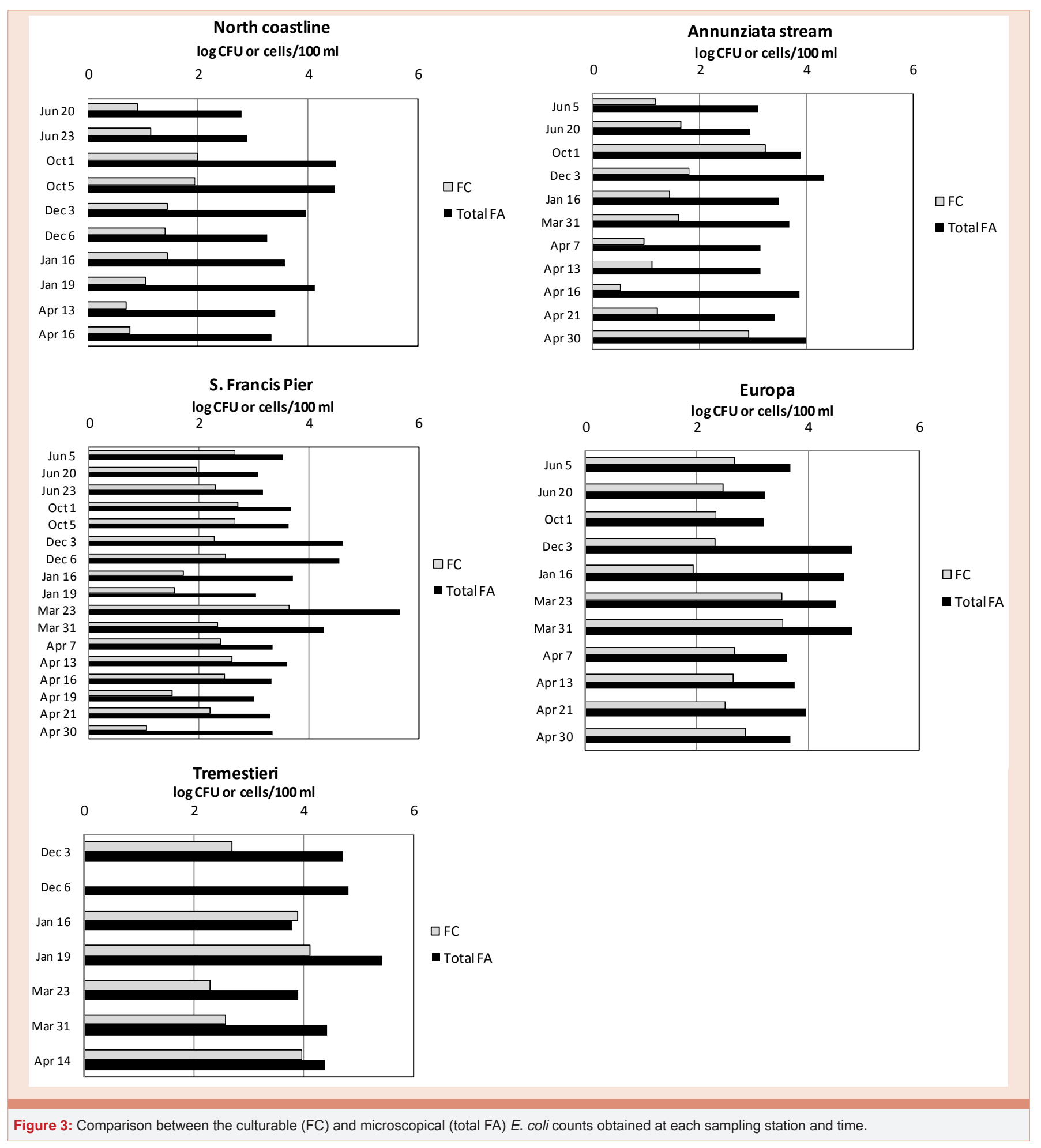

local fecal inputs at the stations S. Francis Pier and Europa, due the occurrence of confined streams. CTC+ cells followed a distribution similar to total FA counts; this suggested the presence of recent fecal wastes, although $E$. coli cells had already lost their ability to grow on culture medium.
On average, $\mathrm{FC}$ values exceeding the limits set for bathing waters (E.coli $500 \mathrm{CFU} / 100 \mathrm{ml}$ ), according to the 2006/7/EC Bathing waters Directive (2006) were found at the stations Tremestieri and Europa. The highest discrepancy between FC and total FA and the high percentage of not labelled E.coli cells found at Tremestieri station 


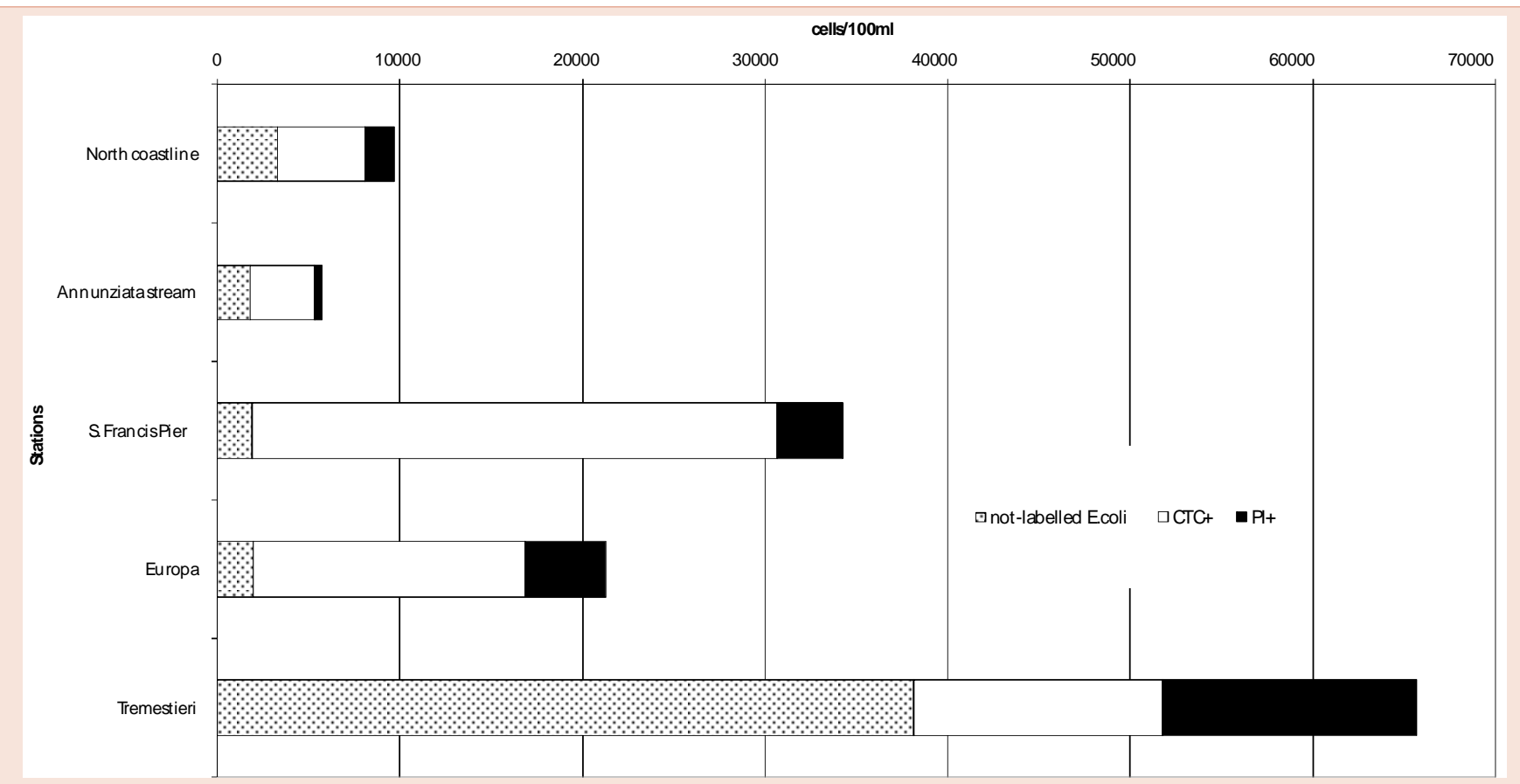

Figure 4: Average values showing the relative contribution of actively respiring (CTC+) and dead $(\mathrm{PI}+)$ cells to the total $E$. coli population, together with cells not labelled by either CTC or PI dyes (not labelled E.coli).

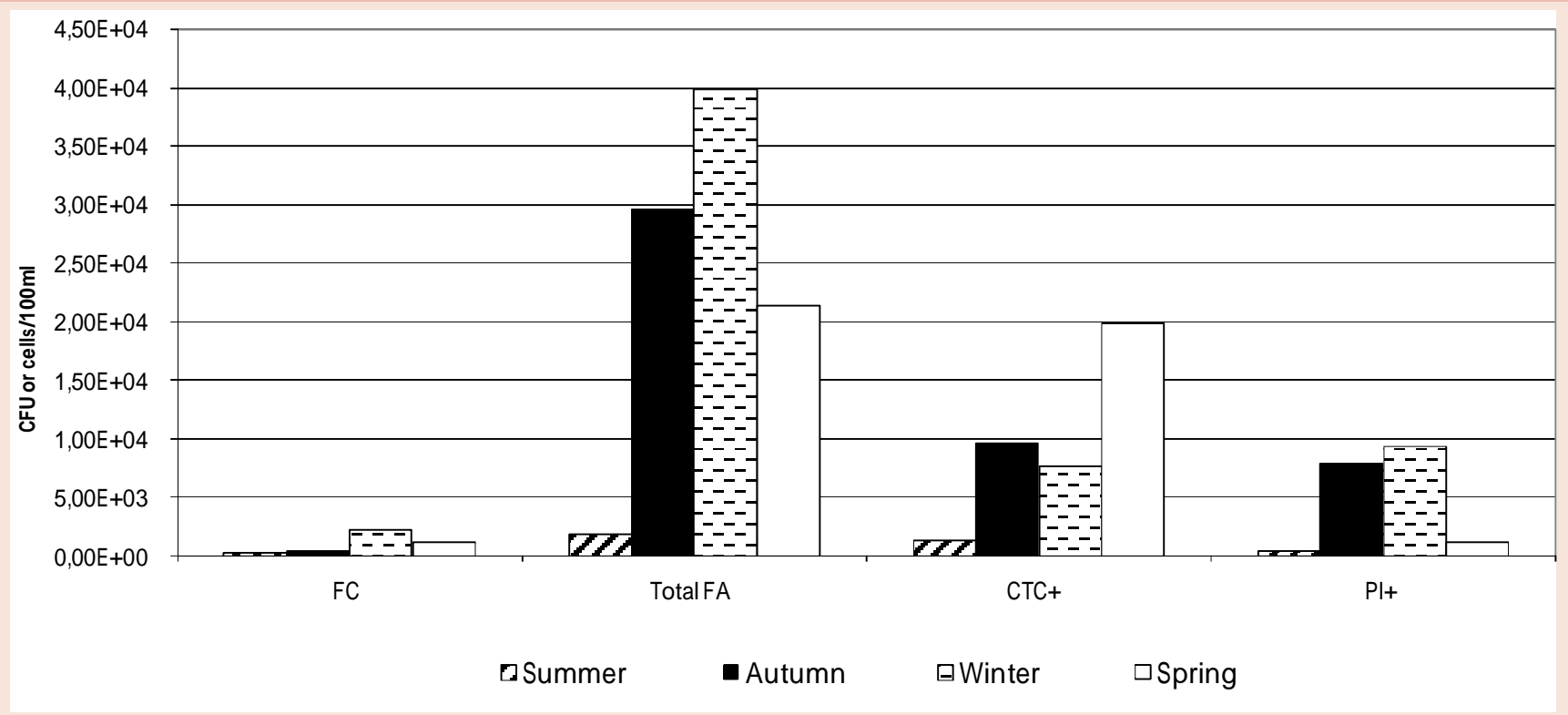

Figure 5: Seasonally averaged data obtained for plate (FC), total microscopical E. coli (total FA), actively respiring (CTC+) and dead E. coli (PI+).

suggested a higher incidence of Viable but Not Culturable (VBNC) forms at this coastal site.

The sum of the percentages of live and dead cells often did not reach $100 \%$ of the total population estimated by the FA method; this suggests that these two components are not the only ones present within the E. coli population, so it is reasonable to assume the presence of another fraction of active cells that may retain attributes of vitality different from those of respiration, determined by CTC, as observed by Caruso et al. [6].

The temporal distribution pointed out the presence of higher bacterial load during the autumn-winter month, with fecal inputs originating mostly from the streams present in Messina town. In 
summer the lower abundances of E.coli found by both FC and FA methods suggested the negative effect of sunlight radiations on bacterial culturability and the improved health condition of coastal marine waters. In winter the culturable (FC) and total cells (FA) increased, suggesting the occurrence of continental run-off; however the percentage of cells having damaged membranes (PI+) increased too, pointing out that E. coli cells did not represent an actual health risk. In this season, cells retaining active respiration (CTC+) accounted for a low percentage of total E.coli population only. In spring, the abundance of actively respiring cells increased, although the total FA counts reduced to half; this suggested that environmental conditions became favorable to the recovery of viability by the stressed E.coli cells.

In this study, specific fluorochromes able to detect specific metabolic or functional activities, such as the respiratory activity (CTC) or the presence of damaged or compromised cell membranes (PI), commonly in use in flow cytometric analysis [12-15], have allowed the implementation of the FA method, making possible to perform a rapid, easy and more precise evaluation of the bacteriological quality of coastal seawater. The FA approach is known to provide a simple methodological tool to characterise bacterial cells at individual cell level, with respect to their physiological and antigenic properties $[7,16]$. However, this method is still experimental and not yet included among the methods currently accepted for bathing waters monitoring [17]. According to previous studies, the data obtained during this investigation confirms that the proposed methodological approach is suitable for E.coli monitoring in seawater. The analytical procedure is quick and provides in a short time ( 2 hours maximum) values which do not differ significantly from those obtained using the standard plate count method. From a quantitative point of view, the discrepancy of 1-2 orders of magnitude observed between plate and microscopical counts was not statistically significant by ANOVA test. This quantitative difference can be explained by the different methodological approaches, since the microscopical count takes into consideration all cells irrespective of their degree of viability and therefore includes also VBNC forms, such as stressed cells. A similar result was previously obtained from Zaccone et al., Caruso et al. $[16,18]$, who confirmed that there is no statistically significant difference between the two methods; moreover, the percentage error between FC and FA decreases to $10 \%$ for heavily polluted samples, having bacterial concentrations of $10^{4} \mathrm{CFU} / 100 \mathrm{ml}$ or higher [18].

The cell viability assay through fluorescent antibody and viability dyes offers an interesting research perspective, with important implications for a more reliable estimate of the bacteriological quality of seawater. The study conducted on our samples has confirmed the existence in natural aquatic environments of many different physiological states within the population of $E$. coli, providing results in a shorter time than that required by the method of Direct Viable Count (DVC, $4 \mathrm{~h}$ ) or by plate counts (18-24h).

\section{Conclusion}

Assessment of the viability of bacterial pathogens is of great importance, when information about potential risks for human health is needed. In ecosystems affected by continuous hydrological changes like the Messina straits, the use of FA-viability staining approach has proved to be a helpful and rapid methodology for the study of short term variations in the abundance and physiological states of $E$. coli population. Nevertheless, no single protocol for the detection of whole cell activity or viability cannot still be proposed, since it has been document that each method is able to detect different factions within the bacterial community and each method has its detection limits. Therefore, to achieve an accurate analysis of the actual abundance of bacterial pathogens the comparison of different methods for estimating the viable fraction is needed.

The combination of FA with CTC or PI can be proposed as an effective tool to discriminate different active and living components within E. coli population.

\section{Work-in-progress}

Developments and improvements in the field of technical detection of bacterial indicators of pollution are constantly in progress, and constitute the challenge for further research perspectives concerning the control and protection of water quality in order to provide operators with analytic tools for rapid and reliable environmental quality controls. The search for new methods will allow both to increase the specificity of target detection and to reduce the time required from analysis to response.

\section{References}

1. Edberg SC, Rice EW, Karlin RJ, Allen MJ (2000) Escherichia coli: the best biological drinking water indicator for public health protection. Symp Ser Soc Appl Microbiol 29: 106S-116S.

2. Lebaron P, Henry A, Lepeuple A-S, Pena G, Servais P (2005) An operational method for the real-time monitoring of $E$. coli numbers in bathing waters. Mar Poll Bull 50: 652-659.

3. Rozen Y, Belkin S (2001) Survival of enteric bacteria in seawater FEMS Microbiol Rev 25: 513-529.

4. Pommepuy M, Butin M, Derrien A, Gourmelon M, Colwell RR, et al. (1996) Retention of enteropathogenicity by viable but nonculturable Escherichia coli exposed to seawater and sunlight. Appl Environ Microbiol 62: 4621-4626.

5. APHA (American Public Health Association) (1992) Standard Methods for the Examination of Water and Waste Water, 18th edition. Edited by American Public Health Association, Washington, DC.

6. Caruso G, Mancuso M, Crisafi E (2003) Combined fluorescent antibody assay and viability staining for the assessment of the physiological states of Escherichia coli in seawaters. J Appl Microbiol 95: 225-233.

7. Caruso G, Zaccone R, Crisafi E (2000) Use of the indirect immunofluorescence method for detection and enumeration of Escherichia coli in seawater samples. Lett Appl Microb 31: 274-278.

8. Williams SC, Hong Y, Danavall DCA, Howard-Jones MH, Gibson D, et al. (1998) Distinguishing between living and nonliving bacteria: Evaluation of the vital stain propidium iodide and its combined use with molecular probes in aquatic samples. J Microbiol Meth 32: 225-236.

9. Rodriguez GG, Phipps D, Ishiguro K, and Ridgway HF (1992) Use of a fluorescent redox probe for direct visualization of actively respiring bacteria. Appl Environ Microbiol 58: 1801-1808.

10. del Giorgio PA, Scarborough G (1995) Increase in the proportion of metabolically active bacteria along gradients of enrichment in freshwater and marine plankton: implications for estimates of bacterial growth and production rates. J Plankton Res 17: 1905-1924. 
11. Sherr BF, del Giorgio P, Sherr E (1999) Estimating abundance and single-cell characteristics of respiring bacteria via the redox dye CTC. Aquat Microb Ecol 18: $117-131$

12. McFeters GA, Yu FP, Pyle BH, Stewart PS (1995) Physiological assessment of bacteria using fluorochromes. J Microbiol Meth 21: 1-13.

13. Porter J, Edwards C, Pickup RW (1995) Rapid assessment of physiological status in Escherichia coli using fluorescent probes. J Appl Microbiol 79: 399 408 .

14. López-Amorós R, Castel S, Comas-Riu J, Vives-Rego J (1997) Assessment of E. coli and Salmonella viability and starvation by Confocal Laser Microscopy and Flow Cytometry using Rhodamine 123, DiBAC4(3), Propidium lodide, and CTC. Cytometry 29: 298-305.
15. Joux F, Lebaron $P(2000)$ Use of fluorescent probes to assess physiological functions of bacteria at single-cell level. Microbes Infect 2: 1523-1535.

16. Caruso G, De Pasquale F, Mancuso M, Zampino D, Crisafi E (2006) Fluorescent Antibody-viability staining and beta-glucuronidase assay as rapid methods for monitoring Escherichia coli viability in coastal marine waters. $J$ Immunoassay Immunochem 27: 1-13.

17. Directive 2006/7/EC of the European Parliament and of the Council of 15 February 2006 concerning the management of bathing water quality and repealing Directive 76/160/EEC, Official Journal of the European Union, L $64 / 37$.

18. Zaccone R, Crisafi E, Caruso G (1995) Evaluation of fecal pollution in coastal Italian waters by immunofluorescence. Aquat Microb Ecol 9: 79-85.

Copyright: (c) 2015 Caruso G, et al. This is an open-access article distributed under the terms of the Creative Commons Attribution License, which permits unrestricted use, distribution, and reproduction in any medium, provided the original author and source are credited. 